\title{
Solvent free microwave assisted preparation of new telechelic polymers based on poly(ethylene glycol)
}

\author{
N. Arsalani ${ }^{*}$, P. Zare ${ }^{1}, H$. Namazi $^{2}$ \\ ${ }^{1}$ Polymer Research Laboratory, Faculty of Chemistry, University of Tabriz, Tabriz, P.O. Box: 51664, Iran \\ ${ }^{2}$ Laboratory of Dendrimers and Biopolymers, Faculty of Chemistry, University of Tabriz, Tabriz, Iran
}

Received 9 February 2009; accepted in revised form 16 April 2009

\begin{abstract}
Poly(ethylene glycol) bis (methylimidazolium chloride) (PEGBMIM) with average molecular weights of 600 and $1000 \mathrm{~g} / \mathrm{mol}$ and poly(ethylene glycol) bis (2-oxazoline) (PEGBOX) with average molecular weight of $600 \mathrm{~g} / \mathrm{mol} \mathrm{have}$ been prepared using microwave irradiation under solvent-free condition. The method described herein is a very good, safe, clean, economical and environmentally friendly alternative to the classical procedures. The resulted products have been characterized by common spectroscopic methods, such as FT-IR (Fourier transform infrared spectroscopy), ${ }^{1} \mathrm{H}$ NMR (Nuclear magnetic resonance of proton) and elemental analysis. Also, the effects of power levels and irradiation time on the yield of reactions and solubility of products have been studied.
\end{abstract}

Keywords: polymer synthesis, molecular engineering, green chemistry, microwave, ionic liquid

\section{Introduction}

Telechelic compounds have found considerable interest as versatile intermediates in many fields. Among these poly(ethylene gycol)-based telechelic compounds due to their salient properties are dominant for many applications in peptide synthesis, modification of enzymes and pharmaceutical industry and so on. Most of these applications require certain end-groups. Therefore, telechelic modification is an important prerequisite for the practical use of such basis telechelics as poly(ethylene glycol) [1-7].

The development of cleaner technologies is a major emphasis in green chemistry. Among the several aspects of green chemistry, using efficient and less hazardous energy sources such as microwave energy is recommended. Polymer synthesis assisted by microwave (MW) has seen spectacular growth over the last few years, specially when this new technique has been coupled with solvent-free procedures, resulting in clean, easy-to-perform, cheap, safe and environmentally friendly conditions which are widely used as synthetic tools under 'Green Chemistry' conditions [8-13]. Therefore, we decided to prepare poly(ethylene glycol) containing imidazolium, which is an ionic liquid, and oxazoline end groups using such a green condition.

Ionic liquids are emerging as a set of new green solvents, mainly as a replacement for conventional volatile organic solvents. Ionic liquids containing 1,3-disubstituted imidazolium cations have shown great promise as an attractive alternative to conventional solvents. The important properties of these ionic liquids are low volatility, negligible vapor pressure, ease of handling, accelerated reaction rates and potential for recycling [13-19]. The preparation of the 1,3-dialkylimidazolium halides via conventional heating method in refluxing the 
solvents requires long time to afford reasonable yields and also need to use a large excess of alkyl halides/organic solvents as the reaction medium in contrast with a few minutes of reaction time using microwave [13, 14, 19]. Although for many years oxazoline and its derivatives played an important role in organic chemistry. They were used, for example as chiral catalysts or optically active reagents. Among all of the possible isomers 1,3oxazoline (2-oxazoline) was the most frequently used [20].

The last few years have brought a growing interest in oxazoline compounds among polymer chemists. Polymer chemistry profits from very high reactivity of oxazoline groups in many ways [21-24]. The examples of using oxazoline functionality for grafting [21], ring opening polymerization [25] or introducing double bonds into polymer [26] are described. Bis-oxazoline compounds were applied as linear chain extenders for polyesters [27, 28] and polyamides [28]. Oxazoline macromonomers [2931] were used to synthesize hyperbranched polymers of various structures [32]. Oxazoline-grafted polymers were used as a nonionic hydrogel for metal complexation [33].

Polymers with oxazoline ring functionality could be obtained by several methods. Reaction between polymer functional groups (acidic, amine) with oxazoline derivatives or bis-oxazoline compounds [26] is one of those. In the present work we have prepared the functional polymer using poly(ethylene glycol) 600 diacid (PEGDA) and $\alpha, \alpha, \alpha-$ tris(hydroxymethyl)methylamine. The direct condensation of carboxylic acids with $\beta$-hydroxylamines requires high temperatures and strongly acidic conditions [34] and therefore is not a synthetically valuable method to access these heterocycles. Here we report the preparation oxazoline ring at the end of a poly(ethylene glycol) under solvent-free condition using microwave irradiation.

Although new hydrophilic ionic liquids, based on poly(ethylene glycol), which are potentially important due to their applications in molecular engineering, secondary batteries, sensors and electrochromic displays have been prepared using the same method.

\section{Experimental}

\subsection{Materials}

1-Methylimidazolium, $\alpha, \alpha, \alpha$-tris(hydroxymethyl) methylamine, thionyl chloride, and poly(ethylene glycol) with average molecular weights of 600 and 1000 (Merck) and poly(ethylene glycol) diacid with average molecular weights of 600 was purchased from Fluka.

\subsection{Instruments}

The ${ }^{1} \mathrm{H}$ NMR spectra of the products recorded on a FT.NMR-Bruker (400 MHz) spectrometer. The FT-IR spectra obtained on a Bruker FT-IR, Tensor 270 spectrometer. Elemental analysis performed using an Elementar, Vario EL III. Reactions were performed in a domestic microwave oven Butan.

\subsection{General Procedure}

\subsubsection{PEGBMIM (a, b)}

Dichloro poly(ethylene glycol) (PEGCl) with different average molecular weights $(5 \mathrm{mmol})$ which were prepared from related poly(ethylene glycol) and thionylchloride [6] and 1-methylimidazole $(11 \mathrm{mmol})$ were placed in a an open glass container. The mixture was irradiated and stirred intermittently in an unmodified household microwave oven under reaction conditions which are outlined in Table 1 (During the reaction the temperature of the mixture reached $115^{\circ} \mathrm{C}$ ). After it was allowed to cool to room temperature, diethylether $(5 \mathrm{ml})$ was added into the mixture to remove excessive starting materials. The residue was washed with diethylether several times and it was vacuum-dried in a desiccator.

\section{Poly(ethylene glycol) bis (methylimidazolium chloride) $1000 \mathrm{~g} / \mathrm{mol}$ (a)}

IR $\left(\mathrm{KBr}, \mathrm{cm}^{-1}\right): \mathrm{v}=3107-3150$ (aromatic C-H stretching), 1633 (aromatic $\mathrm{C}=\mathrm{N}$ stretching), 1469, $1350\left(\mathrm{CH}_{2}\right.$ bending), 1136 (C-O stretching), 625, 655 (aromatic C-H oop). ${ }^{1} \mathrm{H}$ NMR $(400 \mathrm{MHz}$, $\left.\mathrm{CDCl}_{3}, \mathrm{ppm}\right): \delta_{\mathrm{H}}=3.55\left(\mathrm{~m}, \mathrm{O}-\mathrm{CH}_{2}-\mathrm{CH}_{2}-\mathrm{O}\right), 3.77$ $\left(2 \mathrm{H}, \mathrm{t}, \mathrm{O}-\mathrm{CH}_{2}-\mathrm{CH}_{2}-\mathrm{N}\right), 3.94\left(3 \mathrm{H}, \mathrm{s}, \mathrm{N}-\mathrm{CH}_{3}\right), 4.48$ $\left(2 \mathrm{H}, \mathrm{t}, \mathrm{N}-\mathrm{CH}_{2}-\mathrm{CH}_{2}-\mathrm{O}\right), 7.44,7.64(2 \mathrm{H}, \mathrm{C}(4,5)-\mathrm{H})$, $9.87(1 \mathrm{H}, \mathrm{C}(2)-\mathrm{H})$.

Elemental analysis: Calculated for $\mathrm{C}_{52} \mathrm{H}_{100} \mathrm{Cl}_{2} \mathrm{~N}_{4} \mathrm{O}_{21}$ (1217 g/mol): $51.20(\mathrm{C} \%), 8.61(\mathrm{H} \%), 4.60(\mathrm{~N} \%)$. 
Table 1. The yield of the obtained products under different reaction conditions

\begin{tabular}{|c|c|c|}
\hline Product name & Reaction condition: MW/time [W/min] & Yield [\%] \\
\hline $\begin{array}{l}\mathbf{a} \\
\mathbf{a} \\
\mathbf{a} \\
\mathbf{a} \\
\mathbf{a}\end{array}$ & $\begin{array}{l}(300 / 2)+(300 / 5)^{1} \\
(300 / 2)+(300 / 5)+(300 / 5) \\
(300 / 2)+(300 / 5)+(300 / 5)+(300 / 5) \\
(300 / 2)+(300 / 5)+(300 / 5)+(300 / 5)+(300 / 5) \\
(\mathbf{3 0 0 / 2})+(\mathbf{3 0 0 / 5})+(\mathbf{3 0 0 / 5})+(\mathbf{3 0 0 / 5})+(\mathbf{3 0 0 / 5})+(\mathbf{3 0 0 / 5})\end{array}$ & $\begin{array}{l}20 \\
36 \\
57 \\
70 \\
83\end{array}$ \\
\hline $\begin{array}{l}\text { b } \\
\mathbf{b} \\
\mathbf{b} \\
\mathbf{b} \\
\mathbf{b}\end{array}$ & $\begin{array}{l}(300 / 5)+(300 / 5) \\
(300 / 5)+(300 / 5)+(300 / 5) \\
(300 / 5)+(300 / 5)+(300 / 5))+(300 / 5) \\
(300 / 5)+(300 / 5)+(300 / 5)+(300 / 5)+(300 / 5) \\
(\mathbf{3 0 0 / 5})+(\mathbf{3 0 0 / 5})+(\mathbf{3 0 0 / 5})+(\mathbf{3 0 0 / 5})+(\mathbf{3 0 0 / 5})+(\mathbf{3 0 0 / 5})\end{array}$ & $\begin{array}{l}28 \\
34 \\
58 \\
67 \\
76\end{array}$ \\
\hline $\begin{array}{l}\text { c } \\
\text { c } \\
\text { c } \\
\text { c } \\
\text { c }\end{array}$ & $\begin{array}{l}(600 / 2)+(600 / 5) \\
(600 / 2)+(600 / 5)+(600 / 5) \\
(600 / 2)+(600 / 5)+(600 / 5)+(600 / 5) \\
(600 / 2)+(600 / 5)+(600 / 5)+(600 / 5)+(600 / 5) \\
(\mathbf{6 0 0 / 2})+(600 / 5)+(600 / 5)+(600 / 5)+(600 / 5)+(600 / 5)\end{array}$ & $\begin{array}{l}30 \\
45 \\
64 \\
67 \\
79\end{array}$ \\
\hline
\end{tabular}

${ }^{1}$ Irradiation at $300 \mathrm{~W}$ for $2 \mathrm{~min}$, stirring for $1 \mathrm{~min}$ out of oven, again irradiation at $300 \mathrm{~W}$ for $5 \mathrm{~min} . .$.

Found: $52.21(\mathrm{C} \%), 8.74(\mathrm{H} \%), 4.09(\mathrm{~N} \%)$. Conversion: $87.7 \%$.

Poly(ethylene glycol) bis (methylimidazolium chloride) $600 \mathrm{~g} / \mathrm{mol}(\mathrm{b}):$ IR $\left(\mathrm{KBr}, \mathrm{cm}^{-1}\right): \mathrm{v}=3073-$ 3145 (aromatic $\mathrm{C}-\mathrm{H}$ stretching), 1568 (aromatic $\mathrm{C}=\mathrm{N}$ stretching $), 1456,1352\left(\mathrm{CH}_{2}\right.$ bending $), 1107$ (C-O stretching), 627, 655 (aromatic C-H oop). ${ }^{1} \mathrm{H}$ NMR $\left(400 \mathrm{MHz}, \mathrm{CDCl}_{3}, \mathrm{ppm}\right): \delta_{\mathrm{H}}=3.59(\mathrm{~m}$, $\left.\mathrm{O}-\mathrm{CH}_{2}-\mathrm{CH}_{2}-\mathrm{O}\right), 3.83\left(2 \mathrm{H}, \mathrm{t}, \mathrm{O}-\mathrm{CH}_{2}-\mathrm{CH}_{2}-\mathrm{N}\right)$, $4.01\left(3 \mathrm{H}, \mathrm{s}, \mathrm{N}-\mathrm{CH}_{3}\right), 4.54\left(2 \mathrm{H}, \mathrm{t}, \mathrm{N}-\mathrm{CH}_{2}-\mathrm{CH}_{2}-\mathrm{O}\right)$, 7.60, $7.74(2 \mathrm{H}, \mathrm{C}(4,5)-\mathrm{H}), 9.99(1 \mathrm{H}, \mathrm{C}(2)-\mathrm{H})$.

Elemental analysis: Calculated for $\mathrm{C}_{34} \mathrm{H}_{64} \mathrm{Cl}_{2} \mathrm{~N}_{4} \mathrm{O}_{12}$ (791 g/mol): 51.58 (C\%), $8.09(\mathrm{H} \%), 7.07$ (N\%). Found: 49.67 (C\%), 7.81 (H\%), 6.51 (N\%). Conversion: $95 \%$.

\subsubsection{PEGBOX (c)}

Poly(ethylene glycol) 600 diacid $(1 \mathrm{mmol})$ and $\alpha, \alpha, \alpha$-tris(hydroxymethyl)methylamine $(2.2 \mathrm{mmol})$ were placed in an open glass container in such a way as to occupy only $10 \%$ of the overall volume. The mixture was irradiated intermittently in an unmodified domestic (multimode) microwave oven at the power levels indicated in Table 1 (During the reaction the temperature of the mixture reached $138^{\circ} \mathrm{C}$ ). When the irradiation terminated and all of the starting materials disappeared, the mixture was allowed to cool to room temperature. Then, dichloromethane $(5 \mathrm{ml})$ was added at room temperature and the mixture was stirred for some minutes to precipitate unreacted $\alpha, \alpha, \alpha$-tris(hydroxymethyl) methylamine. The resulted mixture was filtered and the obtained clear solution was added into diethyl ether to precipitate the expected functional polymer.

\section{Poly(ethylene glycol) bis (2-oxazoline) $600 \mathrm{~g} / \mathrm{mol}(\mathrm{c})$}

IR $\left(\mathrm{KBr}, \mathrm{cm}^{-1}\right): v=3362(\mathrm{O}-\mathrm{H}$ stretching $), 2880$ (aliphatic $\mathrm{C}-\mathrm{H}$ stretching), 1658 ( $\mathrm{C}=\mathrm{N}$ stretching), 1462, 1352 ( $\mathrm{CH}_{2}$ bending), 1107 (C-O stretching). ${ }^{1} \mathrm{H}$ NMR (400 MHz, DMSO-d $\left.6, \mathrm{ppm}\right): \delta \mathrm{H}=3.62$ (m, $\left.\mathrm{OCH}_{2} \mathrm{O}-\left(\mathrm{CH}_{2} \mathrm{CH}_{2} \mathrm{O}\right)_{\mathrm{n}-2}-\mathrm{CH}_{2} \mathrm{O}\right), 3.96(4 \mathrm{H}, \mathrm{s}$, $\left.\mathrm{C}(3)-\mathrm{CH}_{2} \mathrm{OH}\right), 4.20(2 \mathrm{H}, \mathrm{C}(4)-\mathrm{H}), 4.59(2 \mathrm{H}, \mathrm{b}$, $\left.\mathrm{C}(3)-\mathrm{CH}_{2} \mathrm{OH}\right)$.

Elemental analysis: Calculated for $\mathrm{C}_{30} \mathrm{H}_{56} \mathrm{~N}_{2} \mathrm{O}_{16}$ (700 g/mol): $51.40(\mathrm{C} \%), 8.00(\mathrm{H} \%), 4.00(\mathrm{~N} \%)$. Found: $49.25(\mathrm{C} \%), 7.88(\mathrm{H} \%), 3.80(\mathrm{~N} \%)$. Conversion: $99 \%$.

\section{Results and discussion}

According to Figure 1 derivatives of poly(ethylene glycol) with different average molecular weights have been reacted with 1-methylimidazole and $\alpha, \alpha, \alpha$-tris(hydroxymethyl)methylamine as reactants, separately. The reactions have been performed using microwave irradiation under solventfree condition. So poly(ethylene glycol) bis(3methylimidazolium chloride) and poly(ethylene glycol) containing oxazoline end groups have been prepared. These reactions have been performed in a good yield, quickly and without using chemical solvents. 


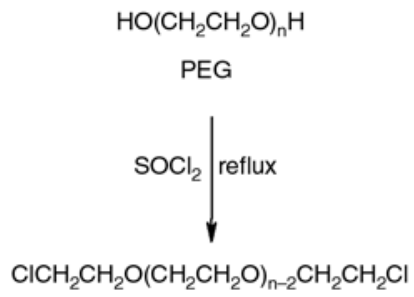

PEGCI

\begin{tabular}{|c|c|}
\hline $\mathbf{n}$ & product \\
\hline 22 & $\mathrm{a}$ \\
\hline 13 & $\mathrm{~b}$ \\
\hline 11 & $\mathrm{c}$ \\
\hline
\end{tabular}

$\mathrm{HOOCCH} \mathrm{O}_{2} \mathrm{O}\left(\mathrm{CH}_{2} \mathrm{CH}_{2} \mathrm{O}\right)_{n-2} \mathrm{CH}_{2} \mathrm{COOH}$

PEGDA

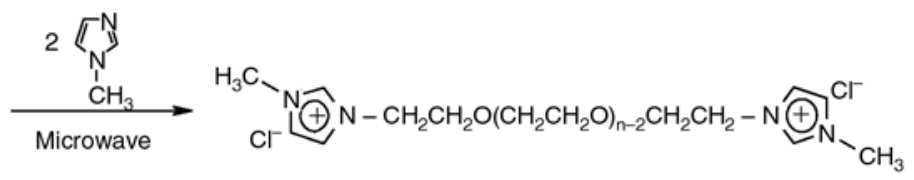

PEGBMIM (a, b)

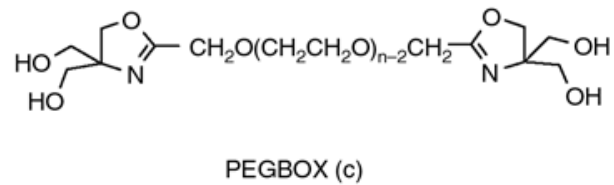

$\operatorname{PEGBOX}(\mathrm{c})$

Figure 1. The reaction route for the preparation of PEGBMIM $(\mathbf{a}, \mathbf{b})$ and PEGBOX $(\mathbf{c})$

The yields of the obtained functional polymers using different reaction conditions are outlined in Table 1. In an unmodified household microwave oven it is not possible to effectively adjust the microwave power. The reduction in power level simply entails that it operates at its full power but for a reduced period of time. Upon microwave irradiation, the product starts forming, which increases the polarity of the reaction medium thereby, increasing the rate of microwave absorption. Perreux and Loupy [35] postulated that a bimolecular reaction between neutral reactants should be assisted by microwave irradiation as the reaction goes through a dipolar transition state. This dipolar transition state is prone to develop more efficient stabilizing electrostatic interactions with the applied electromagnetic field (of a dipole-dipole nature) than the neutral ground state due to dipole formation during the course of the reaction. As a consequence, as the transition state is displaced further along the reaction coordinates (more productlike transition state) the more prone it will be to develop an increased polarity and the more pronounced will be the microwave effect.<smiles>O=C(O)CCCCCCCCCCO</smiles>
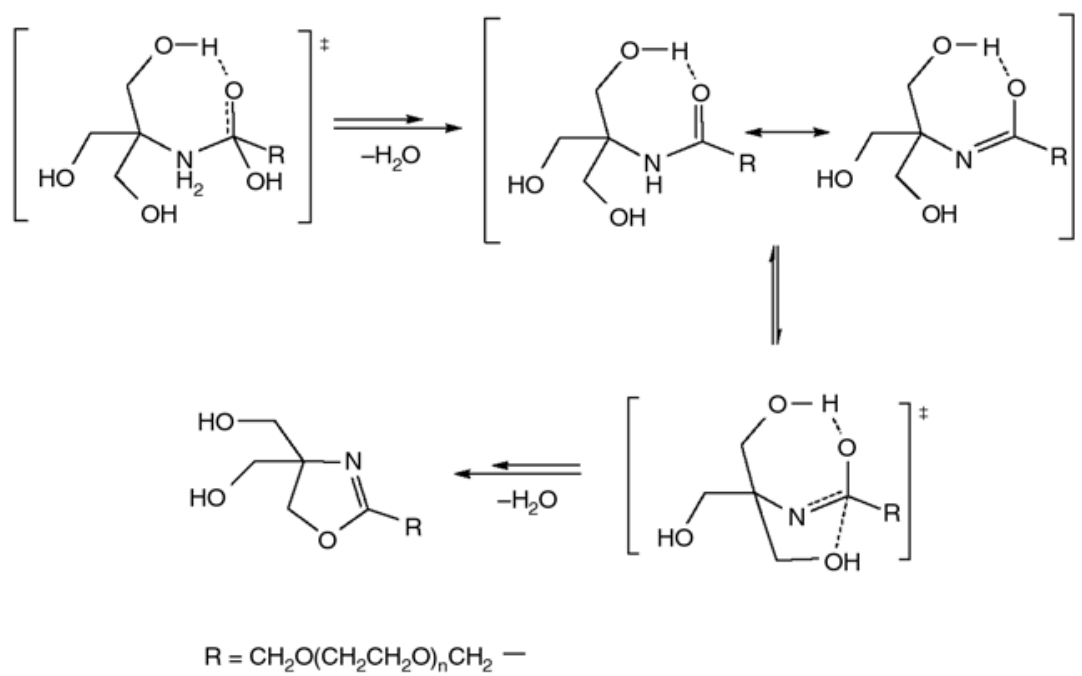

Figure 2. The possible mechanism of the formation of 2-oxazoline from condensation of $\beta$-amino alcohol 
In the process of preparation of ionic liquids it is observed that at elevated power levels partial decomposition/charring of the ionic liquid occurs possibly owing to the localized overheating of ionic liquid, which eventually results in lower yields. To avoid this problem, the reactions are conducted with intermittent heating and mixing at a moderate power level to obtain better yields and cleaner ionic liquid formation. So, we tried to irradiate samples in various conditions at different power levels for different period of times to obtain an optimized condition.

In the case of condensation of acid with $\beta$-amino alcohol, once the amide are formed, subsequent intramolecular condensation between the amide and the free hydroxyl groups present in the molecule can afford 2-oxazoline. The presence of at least two hydroxyl groups in the amino alcohol seems to be crucial to promote the further condensation (Figure 2). In the absence of such a second hydroxyl group, the condensation needs a catalyst to proceed.

Because of the polar nature of the transition states involved in these processes, the microwave irradiation should help to drive the reaction to completion. Furthermore, the final temperature reached $\left(T \sim 140^{\circ} \mathrm{C}\right)$ implies that the formed water is removed from the reaction medium rendering the global process irreversible, irrespective of the mode of activation (MW irradiation or conventional heating).

It is believed [35] that the key role of the second hydroxyl group is to form an internal H-bond with the carbonyl group of the amide to provide some electrophilic assistance for the next condensation. This mechanism is also highly beneficial for MW specific effects as it involves a dipolar transition state from neutral reactants.

Figure 3 shows the FT-IR spectra of the products in comparison with their primary polymers. According to the spectrum the elimination of $\mathrm{C}-\mathrm{Cl}$ stretch-

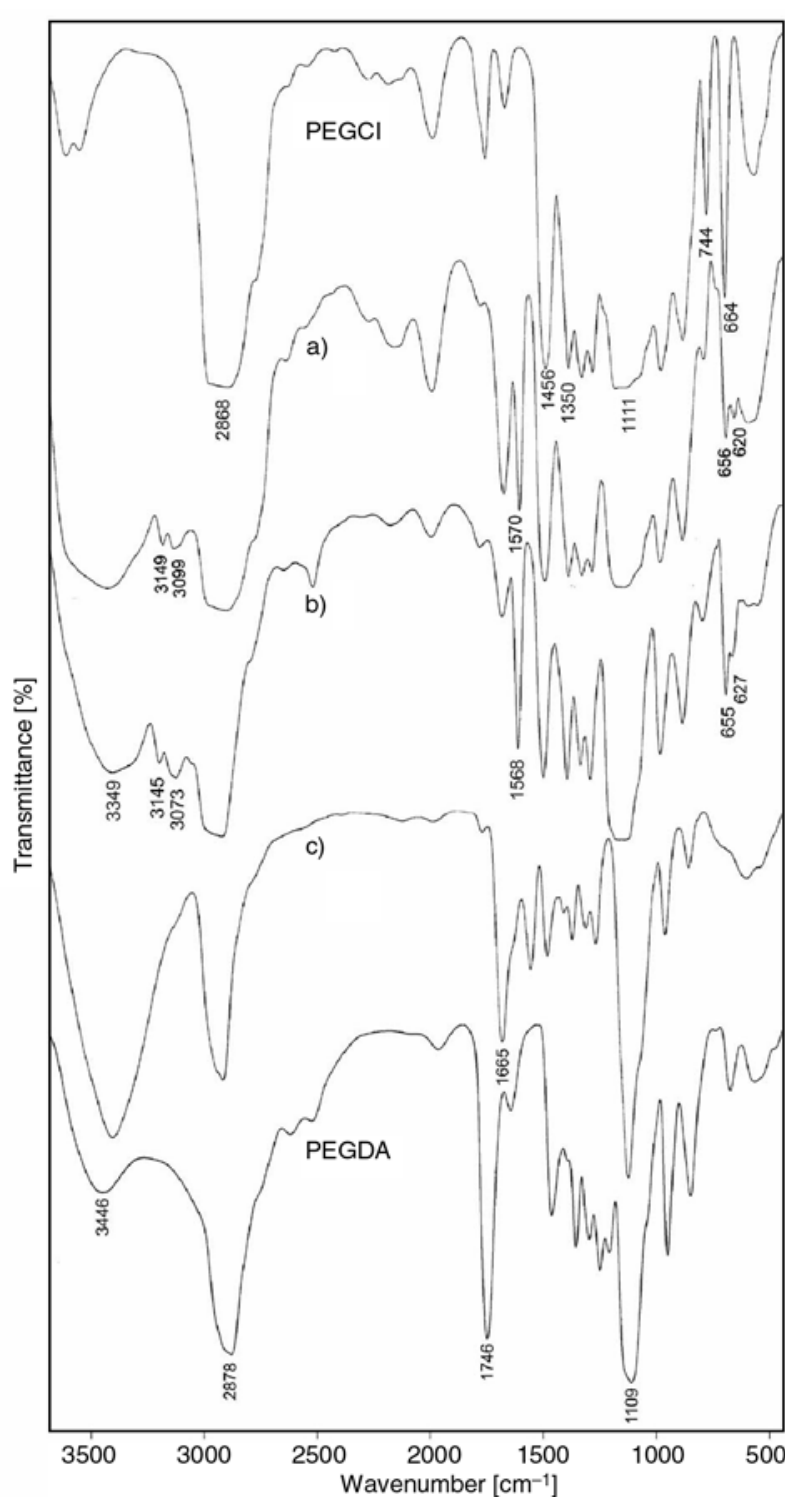

Figure 3. The FT-IR spectra of PEGCl, PEGBMIM (a,b), PEGBOX (c) and PEGDA

ing bands, and the appearance of aromatic $\mathrm{C}-\mathrm{H}$ and $\mathrm{C}=\mathrm{N}$ stretching bands confirm the formation of the expected ionic liquids. Furthermore the elimination of $\mathrm{C}=\mathrm{O}$ stretching band in $1746 \mathrm{~cm}^{-1}$ and the appearance of $\mathrm{C}=\mathrm{N}$ stretching band in $1658 \mathrm{~cm}^{-1}$, confirm the formation of 2-oxazoline.

Table 2. The elemental analysis results of the products

\begin{tabular}{|c|c|c|c|c|c|c|}
\hline & \multicolumn{3}{|c|}{ Content [\%] } & \multirow{2}{*}{$\begin{array}{c}{[\mathrm{C}] /[\mathrm{N}]} \\
{[\%]}\end{array}$} & \multirow{2}{*}{$\begin{array}{c}\text { Conversion } \\
{[\%]}\end{array}$} \\
\hline & & $\mathbf{C}$ & $\mathbf{H}$ & $\mathbf{N}$ & & \\
\hline \multirow{2}{*}{ PEGMIM(a) } & calculated & 51.20 & 8.61 & 4.60 & 13.00 & \multirow[b]{2}{*}{87.8} \\
\hline & found & 52.21 & 8.74 & 4.09 & 14.89 & \\
\hline \multirow{2}{*}{ PEGMIM(b) } & calculated & 51.58 & 8.09 & 7.07 & 8.50 & \multirow[b]{2}{*}{95.0} \\
\hline & found & 49.67 & 7.81 & 6.51 & 8.90 & \\
\hline \multirow{2}{*}{ PEGOX(c) } & calculated & 51.40 & 8.00 & 4.00 & 15.00 & \multirow[b]{2}{*}{99.0} \\
\hline & found & 49.25 & 7.88 & 3.80 & 15.12 & \\
\hline
\end{tabular}




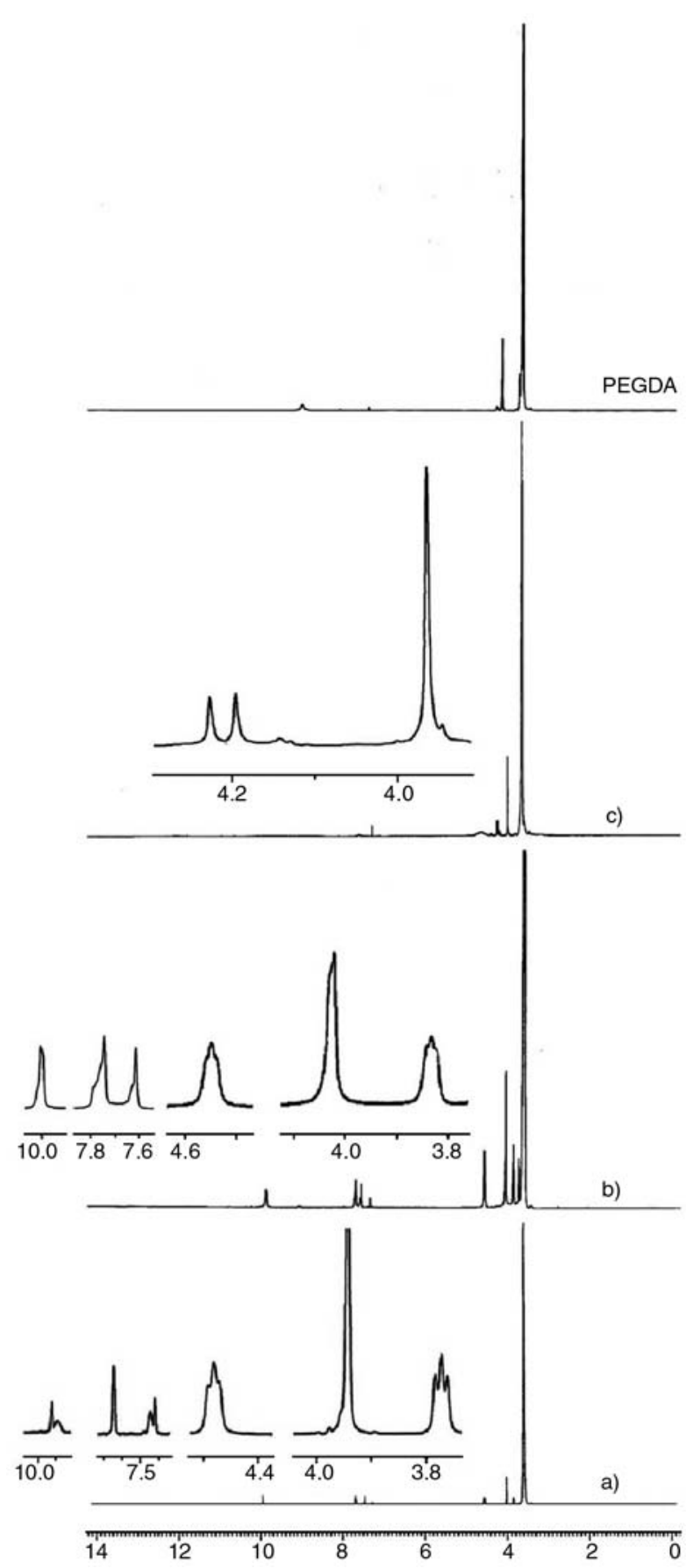

Figure 4. The ${ }^{1} \mathrm{H}$ NMR spectra of PEGBMIM (a,b), PEGBOX (c) and PEGDA

Table 3. The solubility behavior of products in comparison with the primary polymers

\begin{tabular}{|l|c|c|c|c|c|}
\hline \multicolumn{1}{|c|}{ Solvent } & PEGCl & a & b & PEGDA & c \\
\hline Water & $+^{1}$ & + & + & + & + \\
\hline DMF & + & + & + & + & + \\
\hline Dichloromethane & + & + & + & + & + \\
\hline Diethylether & $+^{2}$ & - & - & $+^{3}$ & - \\
\hline n-Hexane & - & - & - & - & - \\
\hline Toluene & + & + & + & \pm & - \\
\hline
\end{tabular}

$1_{+}+$: soluble, - : insoluble, \pm : slightly soluble

${ }^{2,3} \mathrm{PEGCl}$ and PEGDA are insoluble in diethylether below $0^{\circ} \mathrm{C}$
Figure 4 shows the ${ }^{1} \mathrm{H}$ NMR spectra of the products. The appearance of the aromatic protons signals in $\mathbf{a}(7.44,7.64,9.87 \mathrm{ppm})$ and $\mathbf{b}(7.60,7.74$, $9.99 \mathrm{ppm})$, and the elimination of the peak of carboxylic acid groups (8.88 ppm) from PEGDA are evidences of formation of the $\mathbf{a}, \mathbf{b}$ and $\mathbf{c}$ products.

Also the elemental analysis results of the products are shown in Table 2. According to these results, functionalization of the primary polymers has been concluded.

The resulted data showed that, in the case of preparation PEGBMIM (a,b), the obtained dicationic salts generated from dichloro poly(ethylene glycol) are slightly contaminated with the corresponding monocationic intermediate.

The solubility of the synthesized polymers in water and in common organic solvents were studied and the results are shown in Table 3. The results showed that the solubility of the obtained polymers are similar to their parent polymers, but they became polar than primary polymers.

\section{Conclusions}

According to the obtained results poly(ethylene glycol) bis methylimidazolium chloride with average molecular weights of 600 and $1000 \mathrm{~g} / \mathrm{mol}$ and poly(ethylene glycol) bis 2-oxazoline with average molecular weight of $600 \mathrm{~g} / \mathrm{mol}$ have been prepared as a new telechelic polymers under solvent free condition using an unmodified household microwave oven, a method that precludes the usage of volatile organic solvents and is much faster, efficient, and eco-friendly.

\section{References}

[1] Zhang S., Du J., Sun R., Li X., Yang D., Zhang S., Xiong C., Peng Y.: Synthesis of hetrobiofunctional poly(ethylene glycol) with a primary amino group at one end and carboxylate group at the other end. Reactive and Functional Polymers, 56, 17-25 (2003). DOI: 10.1016/S1381-5148(03)00015-4

[2] Henning T.: Polyethylene glycols (PEGs) and the pharmaceutical industry. PharmaChem, June, 57-59 (2002).

[3] Li J., Kao W. J.: Synthesis of polyethylene glycol (PEG) derivatives and PEGylated-peptide biopolymer conjugates. Biomacromolecules, 4, 1055-1067 (2003). DOI: $\underline{10.1021 / \mathrm{bm} 0340691}$ 
[4] Roberts M. J., Bentley M. D., Harris J. M.: Chemistry for peptide and protein PEGylation. Advanced Drug Delivery Reviews, 54, 459-4796 (2002). DOI: $10.1016 / \mathrm{S} 0169-409 \mathrm{X}(02) 00022-4$

[5] Yao N., Jamiseson A. M.: Synthesis and solution properties of cholesterol end capped poly(ethylene glycol). Polymer, 41, 2925-2930 (2000). DOI: 10.1016/S0032-3861(99)00488-7

[6] Bayer E., Zheng H., Geckeler K. E.: Functionalization of soluble polymers. 4. Synthesis of dichloro- and di(4-formylphenyloxyethyl) poly(oxyethelene). Polymer Bulletin, 8, 585-592 (1982). DOI: $\underline{10.1007 / \mathrm{BF} 00262939}$

[7] Geckeler K. E., Arsalani N.: Synthesis and properties of hydrophilic polymers. 4. Preparation and characterization of poly(oxyethylene) telechelics with different aromatic termini. Journal of Macromolecular Science: Pure and Applied Chemistry, 33, 1165-1179 (1996). DOI: $10.1080 / 10601329608010912$

[8] Tanaka K.: Solvent-free organic synthesis. WileyVCH, Weinheim (2003).

[9] Varma R. S.: Solvent-free organic syntheses using supported reagents and microwave irradiation. Green Chemistry, 1, 43-55 (1999). DOI: $10.1039 / \mathrm{a} 808223 \mathrm{e}$

[10] Garcia-Tellado F., Loupy A., Petit A., Marrero-Terrero A. L.: Solvent-free microwave-assisted efficient synthesis of 4,4-disubstituted 2-oxazolines. European Journal of Organic Chemistry, 22, 4387-4391 (2003). DOI: $\underline{10.1002 / \text { ejoc. } 200200469}$

[11] Wiesbrock F., Hoogenboom R., Schubert U. S.: Microwave-assisted polymer synthesis: State-of-theart and future perspectives. Macromolecular Rapid Communications, 25, 1739-1764 (2004). DOI: $10.1002 /$ marc. 200400313

[12] Kappe C. O.: Controlled microwave heating in modern organic synthesis. Angewandte Chemie International Edition, 43, 6250-6284 (2004). DOI: $10.1002 /$ anie.200400655

[13] Varma R. S., Namboodiri V.: An expeditious solventfree route to ionic liquids using microwaves. Chemical Communications, 1, 643-644 (2001). DOI: $10.1039 / \mathrm{b} 101375 \mathrm{k}$

[14] Erdmenger T., Vitz J., Wiesbrock F., Schubert U. S.: Influence of different branched alkyl side chains on the properties of imidazolium-based ionic liquids. Journal of Materials Chemistry, 18, 5267-5273 (2008). DOI: $10.1039 / \mathrm{b} 807119 \mathrm{e}$

[15] Wasserscheid P., Welton T.: Ionic liquids in synthesis. Wiley-VCH, Weinheim (2003).

[16] Xue H., Varma R., Shreeve J. M.: Review of ionic liquids with flurine-containing anions. Journal of Flurine Chemistry, 127, 159-176 (2006). DOI: 10.1016/j.jfluchem.2005.11.007

[17] Welton T.: Room-temperature ionic liquids, solvent for synthesis and catalysis. Chemical Review, 99, 2071-2083 (1999). DOI: $10.1021 / \mathrm{cr} 980032 \mathrm{t}$
[18] Bohm V. P. W., Herrmann W. A.: Coordination chemistry and mechanisms of metal-catalyzed C-C coupling reactions, part 12 . Nonaqueous ionic liquids: Superior reaction media for the catalytic heck-vinylation of chloroarenes. Chemistry A, European Journal, 6, 1017-1025 (2000).

DOI: $10.1002 /($ SICI) 1521-3765(20000317)6:6<1017:: AID-CHEM1017>3.0.CO;2-8

[19] Lewandowski A., Swiderska A.: New composite solid electrolytes based on a polymer and ionic liquids. Solid State Ionics, 169, 21-24 (2004).

DOI: $10.1016 /$ j.ssi.2003.02.004

[20] Kronek J., Luston J., Bohme F.: Reactions of 2-oxazolines and their utilization (in Czech). Chemicke' Listy, 92, 475-485 (1998).

[21] John J., Tang J., Bhattacharya M.: Grafting of oxazoline functional group to polycaprolactone. Journal of Applied Polymer Science, 67, 1947-1955 (1998). DOI: 10.1002/(SICI)1097-4628(19980314)67:11<1947:: AID-APP14>3.0.CO;2-R

[22] Vocke C., Anttila U., Heino M., Hietaoja P., Seppälä J.: Use of oxazoline functionalized polyolefins and elastomers as compatibilizers for thermoplastic blends. Journal of Applied Polymer Science, 70, 1923-1930 (1998).

DOI: $10.1002 /(\mathrm{SICI}) 1097-4628(19981205) 70: 10$ $\leq 1923::$ AID-APP6>3.0.CO;2-4

[23] Hu G-H., Scaffaro R., La Mantia F.: Chemical modification of nitrile to oxazoline functionality on a styrene-acrylonitrile copolymer in the melt. Journal of Macromolecular Science Part A: Pure and Applied Chemistry, 35, 457-474 (1998). DOI: $10.1080 / 10601329808001989$

[24] Wörner Ch., Müller Ph., Mülhaupt R.: 1,3-oxazoline intermediates in reactive processing applications. Polymer, 39, 611-620 (1998). DOI: 10.1002/macp.1995.021960612

[25] Wiesbrock F., Hoogenboom R., Leenen M. A. M., Meier M. A. R., Schubert U. S.: investigation of the living cationic ring-opening polymerization of 2 methyl-, 2-ethyl-, 2-nonyl-, and 2-phenyl-2-oxazoline in a single-mode microwave reactor. Macromolecules, 38, 5025-5034 (2005).

DOI: $10.1021 / \mathrm{ma} 0474170$

[26] Luston J., Böhme F., Komber H., Pompe G.: Unsaturated 2-oxazoline modification of polyethylene containing carboxylic groups. Journal of Macromolecular Science: Pure and Applied Chemistry, 35, 1045-1054 (1998). DOI: $\underline{10.1080 / 10601329808002099}$

[27] Inata H., Matsumura S.: Chain extenders for polyesters. IV. Properties of the polyesters chain-extended by 2,2'-bis(2-oxazoline). Journal of Applied Polymer Science, 33, 3069-3079 (1987). DOI: $\underline{10.1002 / a p p .1987 .070330838}$ 
[28] Chalamet Y., Taha M.: Carboxyl terminated polyamide 12 chain extension using a dioxazoline coupling agent. Journal of Polymer Science Part A: Polymer Chemistry, 35, 3697-3705 (1997).

DOI: $10.1002 /($ SICI) 1099-0518(199712)35:17<3697::

$$
\text { AID-POLA9>3.0.CO;2-P }
$$

[29] Christova D., Velichkova R., Goethals E.: Bis-macromonomers of 2-alkyl-2-oxazolines-synthesis and polymerization. Macromolecular Rapid Communications, 18, 1067-1073 (1997). DOI: $\underline{10.1002 / \text { marc. } 1997.030181210}$

[30] Weber C., Becer R., Baumgaertel A., Hoogenboom R., Schubert U. S.: Preparation of methacrylate endfunctionalized poly(2-ethyl-2-oxazoline) macromonomers. Designed Monomers and Polymers, 12, 149-165 (2009). DOI: $10.1163 / 156855509 X 412090$

[31] Ito K.: Polymeric design by macromonomer technique. Progress in Polymer Science, 23, 581-620 (1998).

DOI: $\underline{10.1016 / S 0079-6700(97) 00049-X}$
[32] Lach C., Hanselmann R., Frey H., Mülhaupt R.: Hyperbranched carbosilane oxazoline-macromonomers: Polymerization and coupling to a trimesic acid core. Macromolecular Rapid Communications, 19, 461-465 (1998).

DOI: 10.1002/(SICI)1521-3927(19980901)19:9<461::

$$
\text { AID-MARC461>3.0.CO;2-8 }
$$

[33] Pantchev I., Velichkova R., Lakov L., Peshev O., Goethals E.: Amphiphilic polyelectrolyte networks derived from 2-oxazolines. Polymer, 39, 7089-7097 (1998). DOI: $10.1016 / \mathrm{S} 0032-3861(98) 00083-4$

[34] Vorbrüggen H., Krolikiewicz K.: A simple synthesis of $\Delta^{2}$-oxazines, $\Delta^{2}$-oxazines, $\Delta^{2}$-thiazolines and 2-substituted benzoxazoles. Tetrahedron, 49, 9353-9372 (1993). DOI: 10.1016/0040-4020(93)80021-K

[35] Perreux L., Loupy A.: A tentative rationalization of microwave effects in organic synthesis according to the reaction medium, and mechanistic considerations. Tetrahedron, 57, 9199-9223 (2001). DOI: $\underline{10.1016 / S 0040-4020(01) 00905-X}$ 